\title{
ENXERTO ÓSSEO DE CALOTA CRANIANA PARA RECONSTRUÇÃO MAXILAR: RELATO DE CASO
}

Edson Oliveira SILVA, Tiago CASSOL, Bento STANG

Rebordos alveolares intensamente comprometidos em maxilares edêntulos aparecem com freqüência como um agravo na recuperação protética dos pacientes. Para a reconstrução destas áreas comprometidas, o emprego de enxertos ósseos autógenos entre as opções reconstrutivas, são os que apresentam melhores resultados clínicos. Os enxertos ósseos autógenos podem ser de origem intra-membranosa ou endocondral de acordo com a sua formação. Os enxertos ósseos autógenos possuem como característica principal a sua conversão em osso vital, através da sua grande capacidade osteogênica e osseoindutora. Os sítios doadores extra-orais de origem intramembranosa, como o enxerto de calota craniana, estão indicados para reconstrução de maxilares extensamente reabsorvidos, pois, permitem a obtenção de grande quantidade óssea e menor grau de remodelação do enxerto. A calota craniana comparado aos outros sítios doadores extra-orais, possui como vantagens, menor dor pós operatória, cicatriz estética, menor tempo de hospitalização do paciente e osso extremamente cortical, demonstrando uma ótima estabilidade do implante osseointegrável. Será apresentado o caso de um paciente do gênero masculino, que após a realização de enxerto ósseo autógeno extra-oral de crista ilíaca, apresentou grande reabsorção, sendo posteriormente submetido à reconstrução de maxila com enxerto de calota craniana.

Palavras- chave: enxerto ósseo, calota craniana, reconstrução. 